\title{
Participation of $14-3-3 \varepsilon$ and $14-3-3 \zeta$ proteins in the phagocytosis, component of cellular immune response, in Aedes mosquito cell lines
}

Abel Trujillo-Ocampo ${ }^{1}$, Febe Elena Cázares-Raga' ${ }^{1}$, Rosa María del Angel ${ }^{1}$, Fernando Medina-Ramírez' Leopoldo Santos-Argumedo², Mario H. Rodríguez ${ }^{3}$ and Fidel de la Cruz Hernández-Hernández ${ }^{1 *}$ (i)

\begin{abstract}
Background: Better knowledge of the innate immune system of insects will improve our understanding of mosquitoes as potential vectors of diverse pathogens. The ubiquitously expressed 14-3-3 protein family is evolutionarily conserved from yeast to mammals, and at least two isoforms of 14-3-3, the $\varepsilon$ and $\zeta$, have been identified in insects. These proteins have been shown to participate in both humoral and cellular immune responses in Drosophila. As mosquitoes of the genus Aedes are the primary vectors for arboviruses, causing several diseases such as dengue fever, yellow fever, Zika and chikungunya fevers, cell lines derived from these mosquitoes, Aag-2 from Aedes aegypti and C6/36 HT from Aedes albopictus, are currently used to study the insect immune system. Here, we investigated the role of 14-3-3 proteins ( $\varepsilon$ and $\zeta$ isoform) in phagocytosis, the main cellular immune responses executed by the insects, using Aedes spp. cell lines.
\end{abstract}

Results: We evaluated the mRNA and protein expression of 14-3-3e and 14-3-3 in C6/36 HT and Aag-2 cells, and demonstrated that both proteins were localised in the cytoplasm. Further, in C6/36 HT cells treated with a 14-3-3 specific inhibitor we observed a notable modification of cell morphology with filopodia-like structure caused through cytoskeleton reorganisation (co-localization of 14-3-3 proteins with F-actin), more importantly the decrease in Salmonella typhimurium, Staphylococcus aureus and E. coli phagocytosis and reduction in phagolysosome formation. Additionally, silencing of $14-3-3 \varepsilon$ and $14-3-3 \zeta$ expression by mean of specific DsiRNA confirmed the decreased phagocytosis and phagolysosome formation of pHrodo labelled E. coli and S. aureus bacteria by Aag-2 cells.

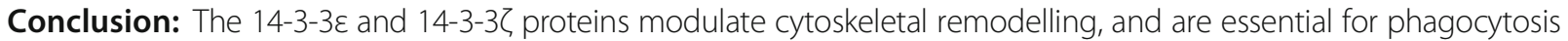
of Gram-positive and Gram-negative bacteria in Aedes spp. cell lines.

Keywords: Aag-2, Ae. aegypti, C6/36 HT, Ae. albopictus, 14-3-3ع, 14-3-3ろ, DsiRNA, 14-3-3 inhibitor, Phagocytosis

\footnotetext{
* Correspondence: cruzcruz@cinvestav.mx

'Departamento de Infectómica y Patogénesis Molecular, Centro de

Investigación y de Estudios Avanzados del Instituto Politécnico Nacional

(CINVESTAV-IPN), Ciudad de México, Mexico

Full list of author information is available at the end of the article
} 


\section{Background}

Phagocytosis by haemocytes is the main innate immune process to eliminate invading bacteria in insects [1-4]. This process is initiated with the recognition of the foreign particle, followed by remodelling of the phagocytic cell cytoskeleton and plasma membrane invagination resulting in internalisation of particles into a phagosome [5]. Phagosomes then undergo serial fusions with endosomes and lysosomes (maturation process), to form a fully functional phagolysosome, where degradation and destruction of ingested particles occur [6]. Several intracellular signalling pathways that drive the insect immune system are similar to those of the mammalian innate immune system [7, 8]. Phagocytosis, a major innate immune process in insects, is crucial for tissue homoeostasis and remodelling since it is required for clearance of apoptotic bodies during embryogenesis and metamorphosis where tissues are remodelled, and cells under programmed death have to be removed [8].

The interference RNA (RNAi) based screening strategy has been used to identify proteins participating in phagocytosis of Gram-negative and Gram-positive bacteria by Drosophila hemocyte S2 cells. The evolutionally conserved protein 14-3-3 $\zeta$ was found to contribute to bacterial engulfment and microbial resistance in insects $[3,9]$. The 14-3-3 proteins in eukaryotic cells are a group of conserved acidic proteins that bind phosphoserine/phosphothreonine motifs. Seven 14-3-3 isotypes $(\alpha / \beta, \gamma, \tau / \theta, \varepsilon, \eta, \sigma, \zeta / \delta)$, encoded by individual genes, have been identified in mammals [10] and two ( $\varepsilon$ and $\zeta)$ in insects, such as Drosophila, Bombyx mori and Aedes aegypti [11-13]. 14-3-3 proteins are also scaffolding proteins that interact with many protein partners to regulate signalling pathways and control cytoskeleton remodelling through the binding of actin molecules, the essential element in phagocytosis [3, 14-16].

Aedes spp. mosquitoes are vectors of disease-causing arboviruses such as dengue, yellow fever, chikungunya and Zika $[17,18]$. In a previous study, we identified two, 14-3-3 $\varepsilon$ and $14-3-3 \zeta$ isoforms in Ae. aegypti, that were highly homologous to the corresponding Drosophila orthologues, suggesting that they may have conserved functional roles in phagocytosis [13]. In this work, we investigated the role of the 14-3-3 isoforms in phagocytosis of Gram-positive and Gram-negative bacteria in the two cell-lines Aag-2 derived from Ae. aegypti and C6/36 HT from Ae. albopictus.

\section{Methods}

\section{Cell culture}

C6/36 HT cells from Ae. albopictus [19], adapted to grow at $34{ }^{\circ} \mathrm{C}$, were cultured in minimum essential medium (Gibco, Thermo Fisher Scientific, Waltham, Mass, USA) supplemented with $7 \%$ fetal calf serum, 0.370 g/l sodium bicarbonate and $50 \mathrm{U} / \mathrm{ml}$ of penicillin and $50 \mu \mathrm{g} / \mathrm{ml}$ of streptomycin $[19,20]$. Ae aegypti Aag-2 cells (kindly provided by Dra. Isabel Salazar from Instituto Politécnico Nacional) were maintained at $28{ }^{\circ} \mathrm{C}$ in Schneider's Drosophila medium with L-glutamine (Gibco, Thermo Fisher Scientific) supplemented with 10\% FCS (Gibco, Thermo Fisher Scientific) adding $50 \mathrm{U} / \mathrm{ml}$ of penicillin and $50 \mu \mathrm{g} /$ $\mathrm{ml}$ of streptomycin; the cells were released from the culture flask with trypsin-EDTA (0.05\%) [20].

\section{Cell viability study}

To evaluate cell viability in the presence of 14-3-3 inhibitor (Antagonist I, 2-5) [21, 22], $8 \times 10^{4}$ cells were grown in 96 well plates $\left(2500\right.$ cells $\left./ \mathrm{mm}^{2}\right)$ until they reached the exponential phase [23]. The first $15 \mathrm{~h}$ the cells remain in the Lag phase of growth. Subsequently, they enter the Log phase of growth; we performed the cell viability at $24 \mathrm{~h}$. Subsequently, cells were gently washed with serum-free medium. The cells were incubated $120 \mathrm{~min}$ at $34{ }^{\circ} \mathrm{C}$ with several concentrations of 14-3-3 inhibitor (dissolved in DMSO) (12.5, 25, 50 and $100 \mu \mathrm{M}$ ), DMSO (vehicle used to dissolve the inhibitor) (Sigma-Aldrich, St. Louis, MO, USA) and medium (without inhibitor) in $100 \mu \mathrm{l}$ of fresh serum free medium. Cells were then incubated with CellTiter $96^{\circ}$ AQueous One Solution Reagent for 60, 120 and $180 \mathrm{~min}$ at $34{ }^{\circ} \mathrm{C}[23,24]$ (Promega Corporation, Madison, WI, USA) according to the manufacturer's protocol. The experiments were performed in triplicate.

\section{Reverse transcriptase polymerase chain (RT-PCR) analysis} Briefly, total RNA was isolated from C6/36 HT and Aag-2 cells using Trizol (Invitrogen, Life Technologies, CA, USA), according to the manufacturer's instructions, and treated with TurboDNase (Thermo Scientific, Waltham, Mass, USA). To synthesise the first strand of cDNA $500 \mathrm{ng}$ of total RNA was used using oligo (dT) primers and SuperScript II reverse transcriptase (Invitrogen, Life Technologies, CA, USA), according to the manufacturer's protocol. Finally, $14-3-3 \varepsilon$ and $14-3-3 \zeta$ transcripts from C6/36 HT and Aag-2 cells were amplified by-PCR using specific primers sets for Aeae14-3-3E (Ae. aegypti,

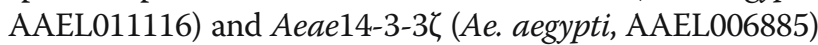
[13]. For PCR amplification samples were preheated at $95^{\circ}$ $\mathrm{C}$ for $4 \mathrm{~min}$, cycling conditions consisted on denaturing at $94{ }^{\circ} \mathrm{C}$ for $1 \mathrm{~min}$, annealing at $58{ }^{\circ} \mathrm{C}$ (Aeal14-3-3E) or $60{ }^{\circ} \mathrm{C}$ (Aeal14-3-3 $\zeta$ and S7) for $1 \mathrm{~min}$ for thirty-five cycles and a final extension step at $72{ }^{\circ} \mathrm{C}$ for $1 \mathrm{~min}$. The Aeal14-3-3E and Aeal14-3-3 $\zeta$ PCR products were sequenced (3500xL Genetic Analyser, Applied Biosystems, Life Technologies) and showed $100 \%$ match with the known sequences of

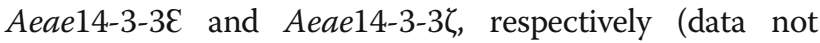
shown). 


\section{Western blot}

Aag-2 and C6/36 HT cells were washed twice with phosphate buffered saline (PBS) and lysed in RadioImmunoprecipitation Assay (RIPA) buffer (25 mM Tris, $150 \mathrm{mM} \mathrm{NaCl}, 0.1 \%$ SDS, $1 \%$ Triton X100) containing Complete $^{\mathrm{TM}}$ protease inhibitors cocktail (Roche Diagnostics, Indianapolis, Ind, USA) and PhosSTOP ${ }^{\mathrm{TM}}$ phosphatase inhibitor cocktail (Roche Diagnostics). Cell lysates were then centrifuged at $16,000 \times g$ at $4{ }^{\circ} \mathrm{C}$ for $12 \mathrm{~min}$, and supernatants were used immediately or stored at $-80{ }^{\circ} \mathrm{C}$ until use. Protein was quantified in the samples using the BCA protein assay (Thermo Scientific). For Western blot, $30 \mu \mathrm{g}$ of protein per lane were resolved in duplicate in 15\% SDS-PAGE, one gel was stained with Coomassie blue and the other electrotransferred onto nitrocellulose (NC) membranes. After blocking with 5\% bovine serum albumin (BSA) in TBS-T, membranes were incubated with rabbit polyclonal to human 14-3-3 (anti14-3-3 K19 SC-629, dilution 1:1000; Santa Cruz Biotechnology, Inc., Dallas, TX, USA) overnight at $4{ }^{\circ} \mathrm{C}$. This antibody is suitable to recognise $14-3-3 \varepsilon$ and $14-3-3 \zeta$ proteins in Ae. aegypti mosquito in dilution of 1:1000 [13], followed by a secondary antibody goat anti-IgG Rabbit-HRP conjugated, (dilution 1: 80,000, Chemicon International, Billerica, Mass, USA). Signals detection was performed using the Supersignal West Pico Chemiluminescent Kit (Thermo Scientific) and an ImageQuant LAS 4000 System (GE Healthcare Life Sciences, Pittsburgh, PA, USA). For Western blotting, actin was used as loading control, NC membranes were stripped using Western Blot Stripping Buffer (Thermo Scientific), and incubated with an anti-actin mouse monoclonal antibody in dilution of 1: 40,000 (Abcam, Cambridge, UK), followed by a goat anti-Mouse IgG-HRP (dilution 1: 50,000, AP308P, Chemicon International). Signal detection was performed as described above.

\section{Immunofluorescence assays}

C6/36 HT cells that were grown to $60 \%$ confluence on coverslips were incubated either with serum-free medium (SFM) alone, SFM with DMSO, or SFM with $100 \mu \mathrm{M}$ of 14-3-3 inhibitor for $120 \mathrm{~min}$ at $34{ }^{\circ} \mathrm{C}$. The cells were fixed with $4 \%$ paraformaldehyde for $30 \mathrm{~min}$ at room temperature, following by permeabilization with PBS containing $0.1 \%$ Triton X-100 for $10 \mathrm{~min}$. After blocking with PBS added of $10 \%$ FCS, 3\% BSA, $10 \mathrm{mM}$ glycine for $60 \mathrm{~min}$ at $37{ }^{\circ} \mathrm{C}$, cells were incubated with rabbit polyclonal anti-14-3-3 (clone K19, 1:100 dilution) and anti-Rabbit IgG Alexa Fluor 647 conjugate (Cell Signaling Technology, Danvers, Mass, USA) as secondary antibody, then cells were incubated with Rhodamine-Phalloidin (ThermoFisher Scientific) for 20 min. DAPI (H-1200, VECTASHIELD, Vector Laboratories Inc., Burlingame, CA, USA) was used to stain nuclei. Fluorescence was visualised under a Zeiss LSM 700 confocal microscope, and images were processed with the ZEN 2009 Light Edition software (Carl Zeiss, Oberkochen, Germany).

\section{Phagocytosis study}

To evaluate phagocytosis, FITC labelled Escherichia coli [25], and Salmonella typhimurium-GFP [26] were incubated with C6/36 HT cells in a 10:1 ratio for $45 \mathrm{~min}$ at $34{ }^{\circ} \mathrm{C}$ or $4{ }^{\circ} \mathrm{C}$ (negative control). Mosquito cells were detached by scraping and resuspended in ice-cold PBS. Engulfed bacteria recorded by flow cytometry in a Cyan ADP Analyzer (Beckman Coulter, Inc., Indianapolis, IN, USA). The fluorescence intensity was acquired in the FL1 channel (FITC/GFP). To evaluate phagosome formation, we utilised pHrodo green Bio Particles - E. coli or Staphylococcus aureus labelled with the acid sensor pHrodo-succinimidyl ester (pHrodo ${ }^{\mathrm{Tm}}$ SE Green, Life Technologies). This dye is activated in acid cell compartments such as phagolysosome [27, 28]. Lyophilized pHrodo green BioParticles were reconstituted in Uptake Buffer (20 mM HEPES in HBSS Hank's balanced salt solution, $\mathrm{pH}$ 7.4, ThermoFisher) at a concentration of $1 \mathrm{mg} / \mathrm{ml}$ prior to use, $50 \mu \mathrm{l}$ of resuspended pHrodo green BioParticles were added to either C6/36 HT cells cultured with 14-3-3 inhibitor or 14-3-3 silenced Aag-2 cells in 24 wells plates for $120 \mathrm{~min}$. Then, cells were detached, single-cell resuspended and subjected to flow cytometric analysis of fluorescence intensity of pHrodo green. The fluorescence intensity was acquired in the FL1/ FL2 channels (pHrodo green-509/540 nm). The cytometry result was expressed as mean fluorescence intensity (MFI), and phagocytosis percentage and phagocytosis percentage of inhibition [25].

\section{Knockdown of $14-3-3 \varepsilon$ and $14-3-3 \zeta$ proteins by DsiRNAs}

27mer Dicer-substrate short interfering RNAs (DsiRNAs) were used to silence 14-3-3 expression. Target sites on DsiRNA14-3-3E (AAEL006885) and DsiRNA14-3-3 (AAEL011116) were designed using software provided in the Integrated DNA Technologies site (IDT; https:// www.idtdna.com/site) following the provider's instructions (Table 1). Briefly, 100 pmol of DsiRNA14-3-3E, DsiRNA14-3-3 $\zeta$ or a negative DsiRNA were incubated with $1.5 \mu \mathrm{l}$ of Lipofectamine ${ }^{\mathrm{TM}}$ RNAiMAX in 24-well tissue culture plates for $20 \mathrm{~min}$ at room temperature. Then, $3.9 \times 10^{5}$ Aag- 2 or C6/36 HT cells were added per well, mix gently and incubated at $28{ }^{\circ} \mathrm{C}$ and $34{ }^{\circ} \mathrm{C}$, respectively. At $24 \mathrm{~h}$ posttransfection, the medium was removed and a second transfection procedure was performed to enhance knockdown efficiencies. After double transfection, the cells were cultured for additional $72 \mathrm{~h}$, and the silencing of 14-3-3 proteins was confirmed from cell lysates using Western blotting as described above. 
Table 1 Templates for DsiRNA generation designed for 14-3-3 silencing. DsiRNAs were synthesised using the custom Dicersubstrate siRNA Construction Kit (IDT, USA). RNA duplex has an asymmetric design with a single 2-base 3'-overhang on the antisense strand and is blunt on the other end; the blunt end is modified with DNA bases marked in bold

\begin{tabular}{|c|c|}
\hline & Sequence $\left(5^{\prime}-3^{\prime}\right)$ \\
\hline \multicolumn{2}{|l|}{ DsiRNA14-3-3E } \\
\hline DsiRNA duplex1For & CAGUCUUCUACUACGAGAUCCUAAA \\
\hline DsiRNA duplex1Rev & UUUAGGAUCUCGUAGUAGAAGACUGAG \\
\hline DsiRNA duplex2For & GGGAGAUUACUACAGAUACCUAGCC \\
\hline DsiRNA duplex2Rev & GGCUAGGUAUCUGUAGUAAUCUCCCUU \\
\hline DsiRNA duplex3For & GGGAAAUCUGCUACGAAGUAUUGGG \\
\hline DsiRNA duplex3Rev & CCCAAUACUUCGUAGCAGAUUUCCCUA \\
\hline \multicolumn{2}{|l|}{ DsRNA14-3-3ろ } \\
\hline DsiRNA duplex1For & GGUCAACAAGACAUAGCAAUUGGAA \\
\hline DsiRNA duplex1Rev & UUCCAAUUGCUAUGUCUUGUUGACCUC \\
\hline DsiRNA duplex2For & CAGUGACAUCGCAAUGACUGACCTT \\
\hline DsiRNA duplex2Rev & AAGGUCAGUCAUUGCGAUGUCACUGGC \\
\hline DsiRNA duplex3For & UCAGCUGAGUGGUGUAUAAAGAGAA \\
\hline DsiRNA duplex3Rev & UUCUCUUUAUACACCACUCAGCUGAUU \\
\hline \multicolumn{2}{|l|}{ DsRNANeg } \\
\hline DsiRNANegFor & Phos-CUUCCUCUCUUUCUCUCCCUUGUGA \\
\hline DsiRNANegRev & UCACAAGGGAGAGAAAGAGGAAGGA \\
\hline
\end{tabular}

\section{Statistical analysis}

GraphPad Prism statistical software package (Prism 5.0; Graph-Pad Software, Inc., San Diego, CA) was used to perform statistical analysis. All data were presented as the mean \pm SEM (standard error of the mean). The statistical comparisons of data between the different conditions were performed using one-way analysis of variance (ANOVA) or Student's $t$-test. $P$-values below 0.05 were considered statistical significance.

\section{Results}

\section{Aedes spp. cells express $14-3-3 \varepsilon$ and $14-3-3 \zeta$ proteins}

We first evaluated the gene expression of Aeae14-3-3ع

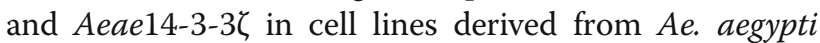
and Ae. albopictus. RT-PCR amplifying specific segments of $14-3-3 \varepsilon$ and $14-3-3 \zeta$ transcripts confirmed that they were highly expressed in C6/36 HT and Aag-2 cells (Fig. 1a, b). In addition, Western blot assays using anti-14-3-3 antibody (clone K-19) demonstrated two bands with the predicted molecular weights of $\sim 30$ and $\sim 29 \mathrm{kDa}$ corresponding to $14-3-3 \varepsilon$ and $14-3-3 \zeta$ protein isoforms, respectively, in both Aag-2 and C6/36 HT cells (Fig. 1c). The abundance in the expression of the two 14-3-3 isoforms was similar in the two cell lines (Fig. 1c). Lastly, intracellular distribution of 14-3-3 proteins was assessed using Immunofluorescence assay as 14-3-3 protein family interacts with other proteins and may have a distinct pattern of intracellular expression $[29,30]$. The 14-3-3
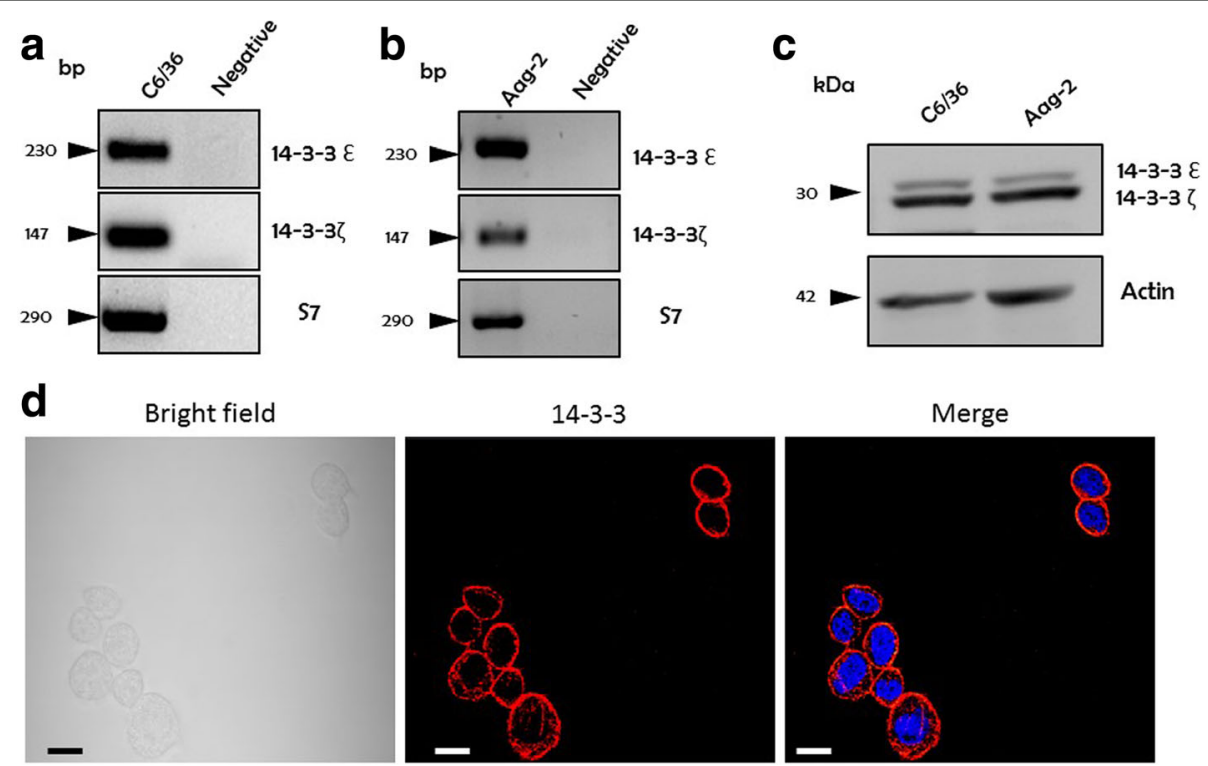

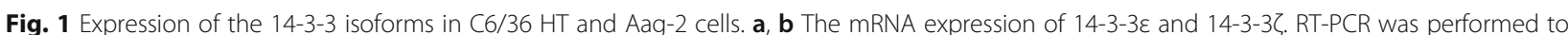

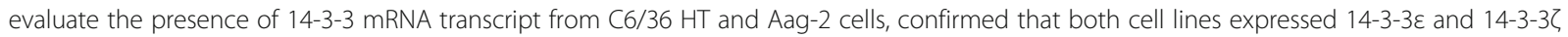
isoforms at the mRNA level. S7 mRNA was used as an internal control. c 14-3-3 protein expression in C6/36 HT and Aag-2 cells. Cell lysates were assessed for the presence of 14-3-3 proteins by Western blot, which demonstrated two distinctive bands with the predicted sizes of 30 and $29 \mathrm{kDa}$ corresponding to $14-3-3 \mathcal{E}$ and 14-3-3 , protein isoforms, respectively in C6/36 HT and Aag-2 cells. d Intracellular distribution of 14-3-3 proteins in C6/36 HT cells. The immunofluorescent staining of 14-3-3 proteins reveals the presence of the 14-3-3 proteins (red) in the cytoplasm of $\mathrm{C} 6 / 36 \mathrm{HT}$ cells. Nuclei were stained with DAPI (blue). Scale-bars: $10 \mu \mathrm{m}$ 
proteins, in basal conditions, were in the cytoplasm, mainly with a cortical distribution (Fig. 1d).

\section{Effect of 14-3-3 inhibitor on C6/36 HT cells phagocytosis} To investigate the role of 14-3-3 in C6/36 HT cells functions, we assessed whether 14-3-3 inhibitor affects the cell viability, and found that viability was maintained at $90 \%$ even with highest concentration used $(100 \mu \mathrm{M})$ and prolonged incubation time (180 min) (Fig. 2). In addition, we also evaluated whether the inhibitor induced disruption of protein-protein interaction with 14-3-3 had impact on phagocytosis. The treatment with 14-3-3 inhibitor in different concentrations ranging from $12.5 \mu \mathrm{M}$ to $100 \mu \mathrm{M}$ showed a significant reduction on phagocytosis of $S$. typhimurium-GFP, of $60 \%$ (Kruskal-Wallis test: $\chi^{2}=10.38$, $d f=5, P=0.015$; t-test: $t=7.318, P=0.0019), 40 \%$ (Kruskal-Wallis test: $\chi^{2}=10.38, d f=5, P=0.015$; t-test: $t=4.266, P=0.01$ ) and 20\% (Kruskal-Wallis test: $\chi^{2}=10.38$, $d f=5, P=0.015$; t-test: $t=3.277, P=0.030)$ of inhibition at concentrations of $100 \mu \mathrm{M}, 50 \mu \mathrm{M}$ and $25 \mu \mathrm{M}$ of 14-3-3 inhibitor, respectively (Fig. 3a). Comparable results were obtained in phagocytosis of FITC-E. coli, leading to a statistically significant decrease by up to $60 \%$ (t-test: $t=2.941, P=0.0022$ ), with $50 \mu \mathrm{M}$ of the inhibitor (Fig. 3b).

To further examine the participation of 14-3-3 in phagocytosis and phagosome maturation, we used pHrodo E. coli and S. aureus bioparticles in the presence of 14-3-3 inhibitor [31]. The pHrodo E. coli phagocytosis-phagosome formation decreased 50\% (Kruskal-Wallis test: $\chi^{2}=13.04$, $d f=5, P=0.011$; t-test: $t=94.27, P<0.0001)$ with $14-3-3$ inhibitor concentrations of 12.5 and $25 \mu \mathrm{M}$, and $60 \%$ (Kruskal-Wallis test: $\chi^{2}=13.04, d f=5, P=0.011$; t-test: $t=37.40, P<0.0001)$ with concentrations of 50 and $100 \mu \mathrm{M}$ (Fig. 4). The pHrodo-S. aureus phagocytosisphagosome formation was also reduced in the presence of 14-3-3 inhibitor; $10 \%$ (Kruskal-Wallis test: $\chi^{2}=13.52, d f=5$, $P=0.0090$; t-test: $t=8.315, P=0.0011)$ at a concentration of $12.5 \mu \mathrm{M}$ of inhibitor, $15 \%$ (Kruskal-Wallis test: $\chi^{2}=13.52, d f=5, P=0.0090$; t-test: $\left.t=8.500, P=0.001\right)$ at a concentration of $25 \mu \mathrm{M}, 30 \%$ (Kruskal-Wallis test: $X^{2}=13.52, d f=5, P=0.0090$; t-test: $\left.t=17.06, P<0.0001\right)$ at a concentration of $50 \mu \mathrm{M}$ and $50 \%$ (Kruskal-Wallis test: $\chi^{2}=13.52, d f=5, P=0.0090$; t-test: $\left.t=16.40, P<0.0001\right)$ at a concentration of $100 \mu \mathrm{M}$. These inhibitions were statistically significant at all concentrations (Fig. 5).

\section{4-3-3 inhibitor effect on the cytoskeleton organisation}

To investigate the role of 14-3-3 proteins in actin cytoskeleton organisation, we assessed the expression pattern of actin and 14-3-3 in C6/36 HT cells in the presence or absence of 14-3-3 inhibitor. In medium and DMSO control cells, F-actin was localised mainly at the cell cortex, and 14-3-3 was present in the cytoplasm and near the cell membrane. At 120 min after treatment with 14-3-3 inhibitor, cells became elongated (prismatic), actin reorganised and co-located with 14-3-3 in filopodia-like structures (Fig. 6).

\section{DsiRNAs mediated 14-3-3 silencing on C6/36 HT and Aag-2 cells}

We attempted to investigate the role of 14-3-3 proteins in phagocytosis in Aedes spp. cell lines by "knockdown" of genes with DsiRNAs. Double transfection with DsiRNAs onto C6/36 HT cells did not elicit any major morphological changes compared with C6/36 HT cells transfected with controls (Fig. 7a) and no change in expression of $14-3-3 \zeta$, and $14-3-3 \varepsilon$ isoform proteins $(P>0.05)$ was observed (Fig. $7 \mathrm{~b}, \mathrm{c})$.

In contrast, Aag-2 cells transfected with DsiRNA14-3-3e and DsiRNA14-3-3 $\zeta$ dramatically underwent changes in their morphology from monolayer surface to a rounded cluster of cells, which has been described only in stress conditions (Fig. 8a) [32-34]. Moreover, the expression of both $14-3-3 \varepsilon$ and $14-3-3 \zeta$ proteins was significantly
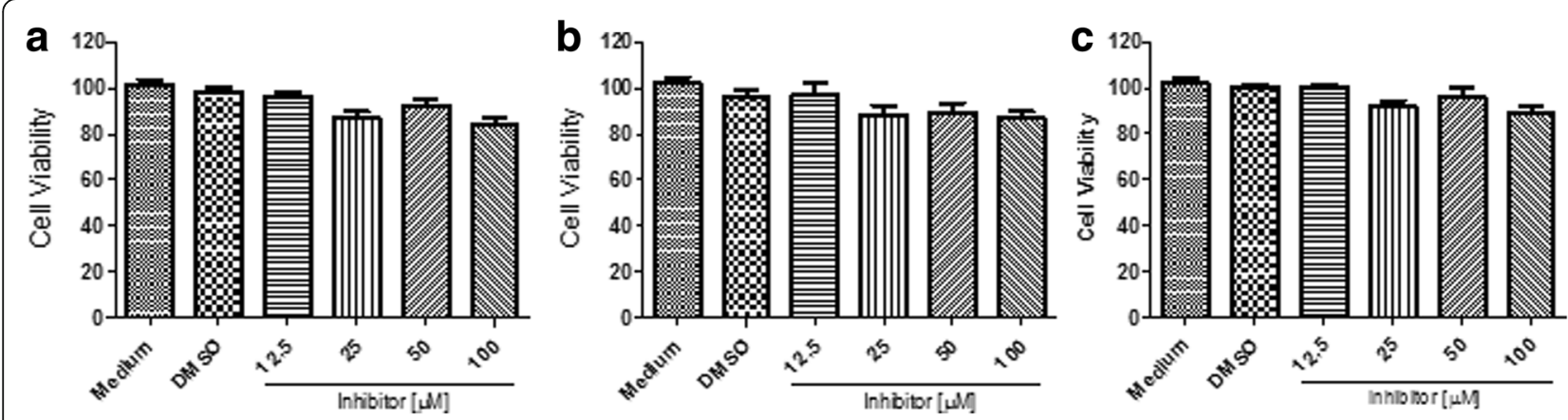

Fig. 2 Effect of the 14-3-3 inhibitor on the viability of C6/36 HT cells. C6/36 HT cells were treated with various 14-3-3 inhibitor concentrations ranging from $12.5 \mu \mathrm{M}$ to $100 \mu \mathrm{M}$ for different times: at $60 \mathrm{~min}(\mathbf{a}), 120 \mathrm{~min}(\mathbf{b})$ and $180 \mathrm{~min}(\mathbf{c})$, and cell viability was assessed. DMSO and medium alone were used as controls. Even prolonged treatment with 14-3-3 inhibitors, cell viability, was maintained at greater than 90\%. Experiments were performed in triplicate; three independent experiments were conducted and represented as the mean \pm standard error, SE 

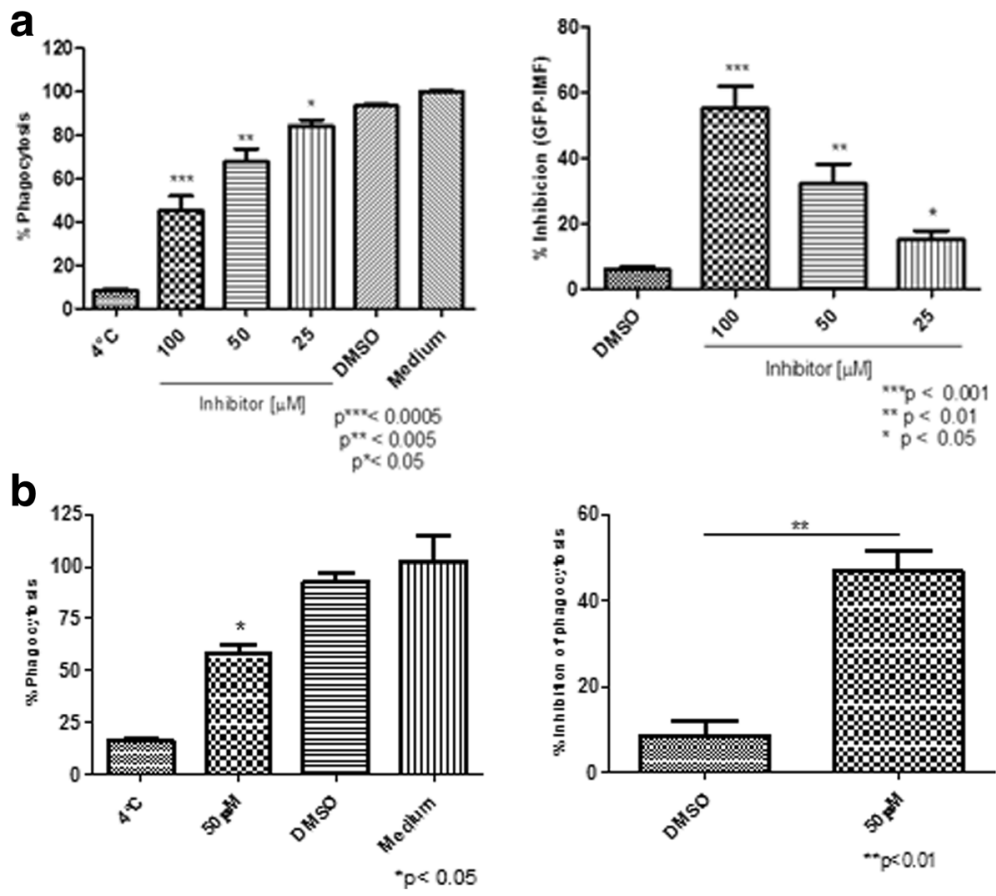

Fig. 3 Effect of the 14-3-3 inhibitor on the phagocytosis of S. typhimurium-GFP and FITC-labeled E. coli in C6/36 HT cells. C6/36 HT cells pre-treated with 14-3-3 inhibitor at various concentrations were evaluated for phagocytosis of S. typhimurium-GFP (a) and FITC-labeled E. coli (b). Phagocytosis of both S. typhimurium and E. coli was significantly decreased by the treatment with 14-3-3 inhibitors in a dose-dependent manner. DMSO and medium alone, as well as phagocytosis performed at $4{ }^{\circ} \mathrm{C}$, were used as negative control. Experiments were performed in triplicate, and data from three experiments are presented as the mean \pm standard error, $\mathrm{SE}$
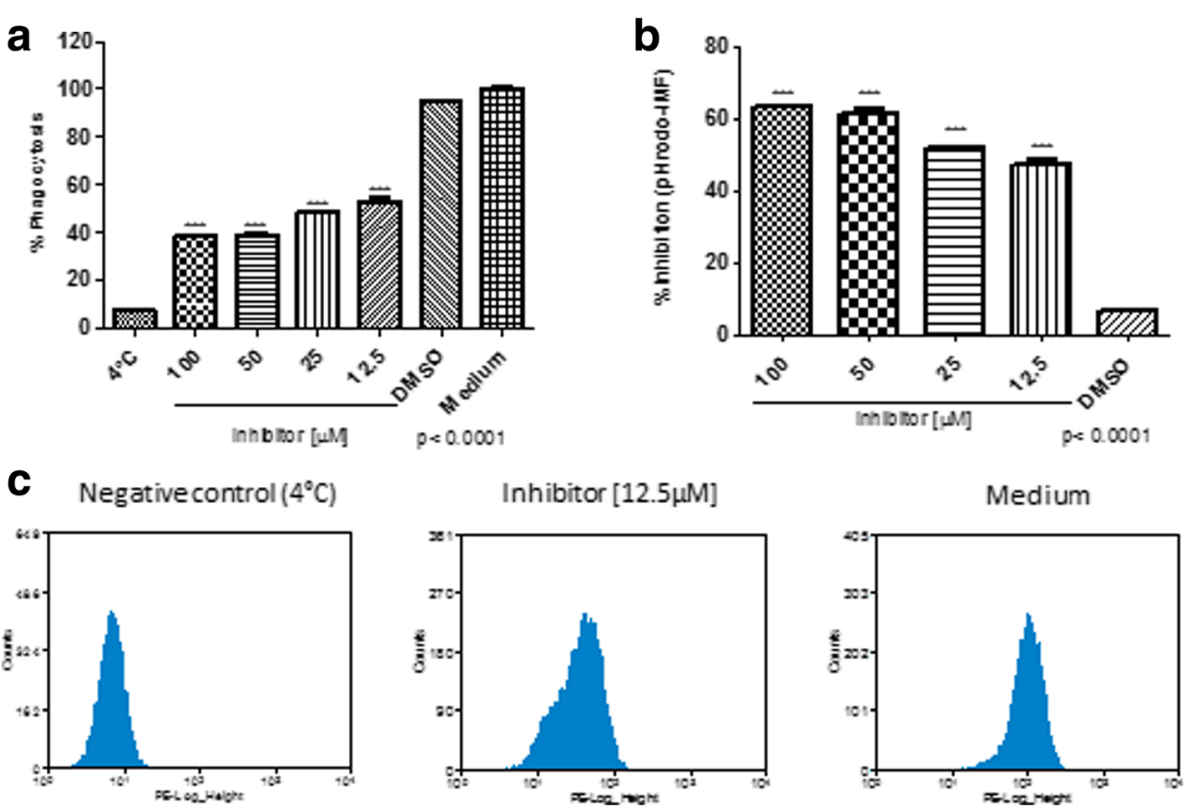

Fig. 4 Inhibition of E. coli -containing phagosome formation by the 14-3-3 inhibitor in C6/36 HT cells. C6/36 HT cells were treated with 14-3-3 inhibitor in different concentrations and evaluated for the ability to form phagosome with pHrodo green E. coli bacteria. Phagosome formation $(\mathbf{a}, \mathbf{b})$ was significantly reduced by the treatment with inhibitors in dose-dependent manner (c) Representative histograms of phagosome formation by untreated $\mathrm{C} 3 / 36 \mathrm{HT}$ cells on ice (left, negative control, $4{ }^{\circ} \mathrm{C}$ ), treated with $12.5 \mu \mathrm{M}$ of 14-3-3 inhibitor (middle), and untreated C6/36 HT cells at $34^{\circ} \mathrm{C}$, in medium (right, positive control). Experiments were performed in triplicate and represented as the mean \pm standard error, SE. Representative data from three independent experiments are shown 


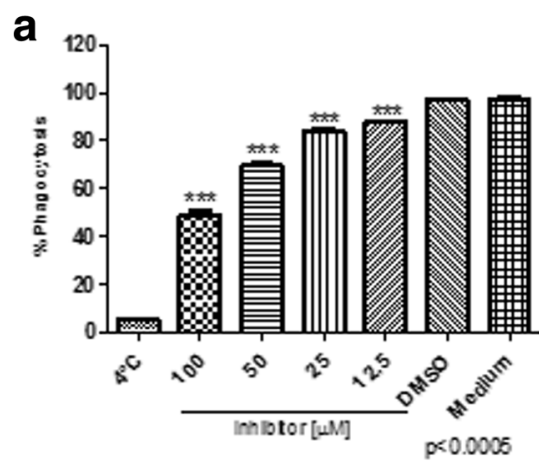

C Negativecontrol $\left(4^{\circ} \mathrm{C}\right)$

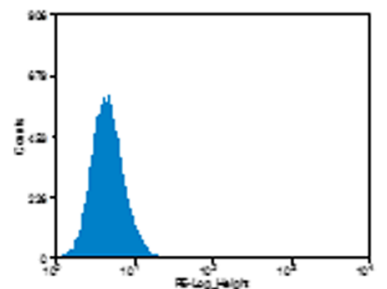

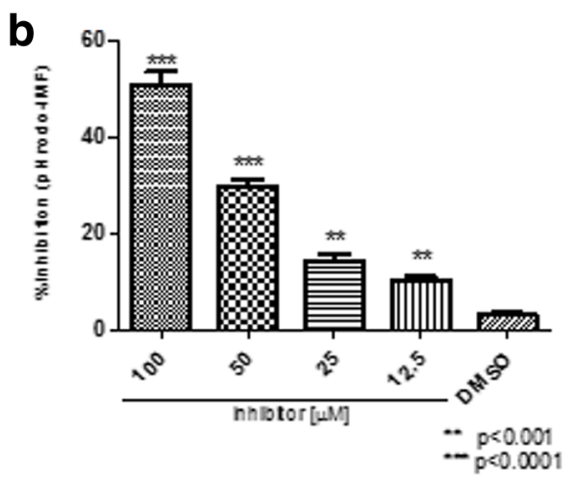
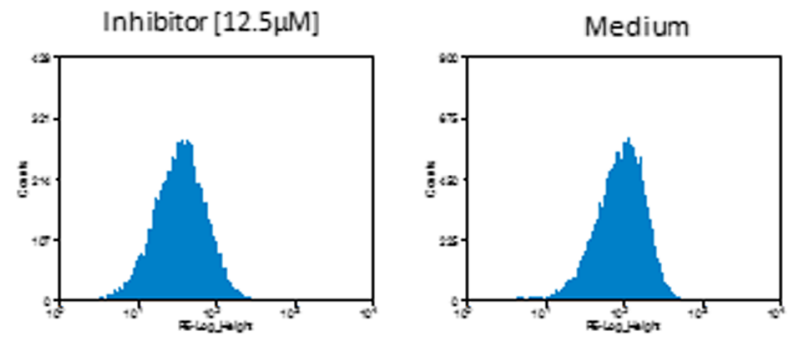

Fig. 5 Inhibition of S. aureus -containing phagosome formation by the 14-3-3 inhibitor in C6/36 HT cells. C6/36 HT cells were treated with 14-3-3 inhibitor at different concentrations and evaluated for the ability to form phagosome with pHrodo green $S$. aureus bacteria. Again, phagosome formation (a, b) was significantly reduced by the 14-3-3 inhibitor in a dose-dependent manner. (c) Representative histograms of phagosome formation by phagosome formation by untreated C3/36 HT cells on ice (left, negative control), treated with $12.5 \mu \mathrm{M}$ of 14-3-3 inhibitor (middle), and untreated $\mathrm{C} 3 / 36 \mathrm{HT}$ cells at $34^{\circ} \mathrm{C}$, in medium (right, positive control). Experiments were performed in triplicate and represented as the mean \pm standard error, SE. Representative data from three independent experiments are shown

reduced to 50 and $75 \%$, respectively (t-test: $t=30.75$, $P=0.0011$ ) (Fig. 8b, c).

The effect to $14-3-3 \varepsilon$ and $14-3-3 \zeta$ silencing showed the impaired phagocytosis-phagosome formation of pHrodo green E. coli in Aag-2 cells.

Finally, we examined whether DsiRNA mediated silencing for $14-3-3 \varepsilon$ and $14-3-3 \zeta$ affects the phagocytosisphagosome formation of pHrodo E. coli in Aag-2 cells. We observed a significant reduction on phagocytosisphagosome formation of pHrodo $E$. coli of 30\% (t-test: $t=12.72, P=0.0061)$ and $20 \%$ (t-test: $t=28.76$, $P=0.0012$ ) for $14-3-3 \varepsilon$ and $14-3-3 \zeta$, respectively (Fig. 9). Taken together, DsiRNA treatment effectively reduced the expression of 14-3-3 scaffold proteins, which led to significant reduction of the phagocytosis-phagosome formation of bacteria.

\section{Discussion}

The members of the $14-3-3$ family are $28-30 \mathrm{kDa}$ acidic proteins highly conserved in a wide range of organism and tissues [35]. The 14-3-3 proteins interact as adapters, activators and repressors with several other protein partners, regulating signalling pathways in a vast array of processes such as apoptosis, cell signalling and cytoskeletal organisation $[11,36,37]$.

Previously, two isoforms of $14-3-3 \varepsilon$ and $14-3-3 \zeta$ have been shown to be present in insects such as Drosophila,
B. mori and Ae aegypti $[9,12,13,38]$. In this work, we documented the expression and function of Aeae14-3-3e and Aeae14-3-3 $\zeta$ in C6/36 HT cells derived from Ae. albopictus and Aag-2 cells derived from Ae. aegypti as model systems from insect vectors of human diseases. We found that 14-3-3 proteins were localised in the cytoplasm in Aedes spp. cells in accordance to those observed in Ae. aegypti midguts [13]. This cellular distribution is similar to those observed in cells of several tissues of other insects, such as B. mori [38] and Pieris rapae [36]. This is important since on the isoforms that are present in different cellular locations under certain cellular conditions [29].

To investigate functions of 14-3-3 in C6/36 HT cells, we used a membrane-permeable specific inhibitor, which disrupts the formation of the functional complex through interactions with their protein partners [21, 22]. 14-3-3 inhibitor had not impacted on the viability of mosquito cells in the dose range tested $(90 \%$ viability after $180 \mathrm{~min}$ ), indicating that the observed functional effect in our study was not the result of cell damage. The 14-3-3 inhibitor-induced cytoskeletal reorganisation on C6/36 HT cells which led to changes in cell shape and co-localization of 14-3-3 proteins with F-actin in filopodium-like structures (Additional file 1: Fig. S1, Additional file 2: Fig. S2). In Drosophila, 14-3-3 proteins have been suggested to interact with several regulators 


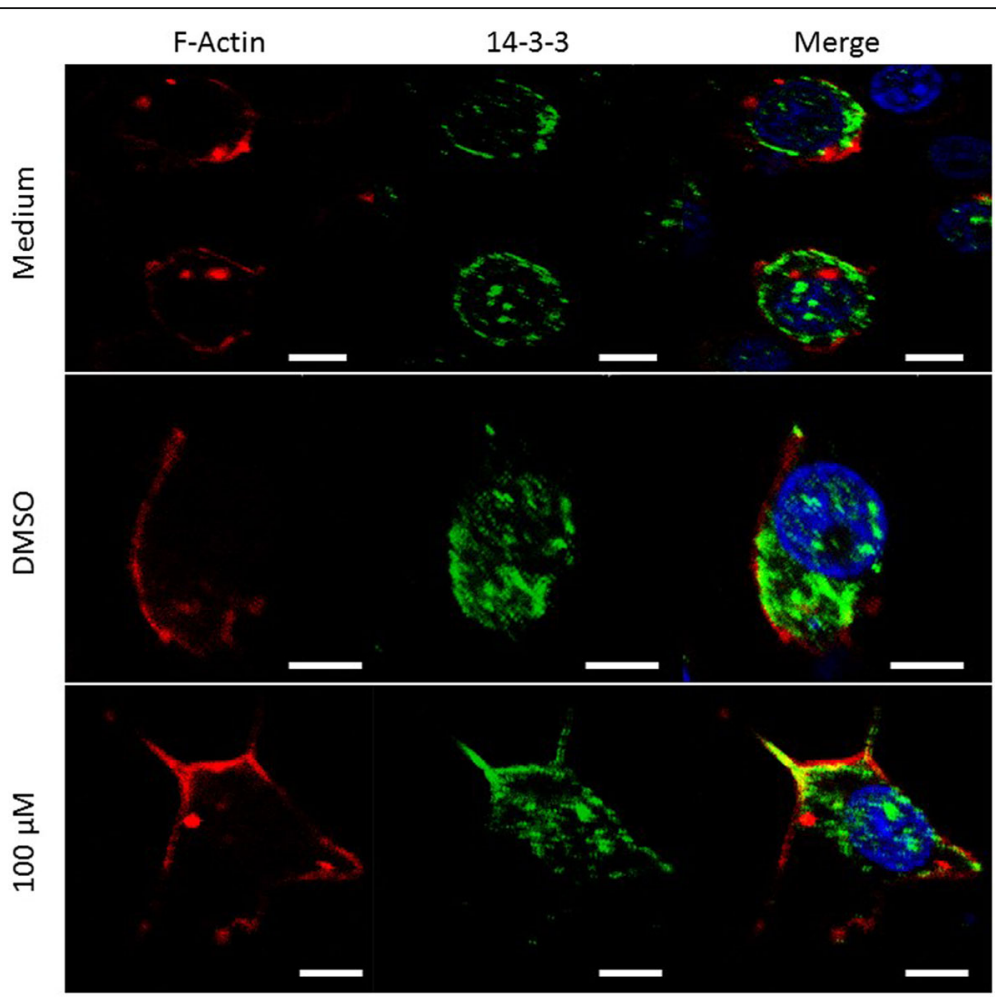

Fig. 6 Effect of the 14-3-3 inhibitor on the cytoskeleton organisation of C6/36 HT cells. The intracellular distribution of 14-3-3 proteins (green), actin (red), and nuclei (blue) on C6/36 HT cells treated with 14-3-3 inhibitor, DMSO and medium were visualised by Immunofluorescence. In medium or DMSO treated cells, 14-3-3 proteins were present mainly in the cytoplasm and did not co-localized with F-actin in the cortex. In contrast, cells treated with 14-3-3 inhibitors underwent morphologic changes, e.g. elongation through reorganisation of F-actin and colocalizing with 14-3-3 proteins. Scale-bars: $5 \mu \mathrm{m}$

\section{a}

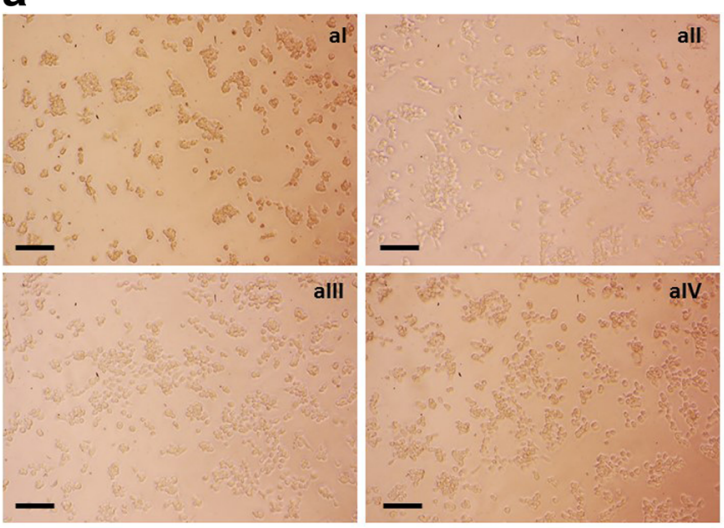

b

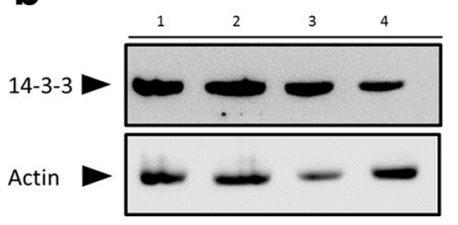

C

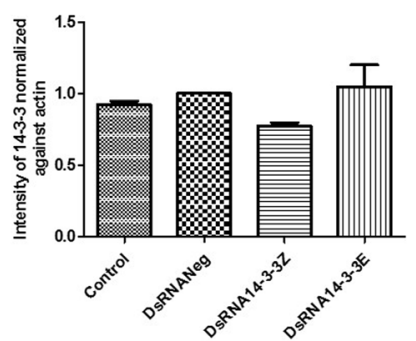

Fig. 7 DsiRNAs effect on 14-3-3 $\varepsilon$ and 14-3-3 expression, in C6/36 HT cells. a C6/36 cells were double transfected with DsiRNA targeting 14-3-3, and expression of $14-3-3 \mathcal{E}$ and $14-3-3 \zeta$ proteins was assessed by Western blot. Optical microscopy images of C6/36 HT cells treated with (al) DsiRNA 14-3-3E and (all) DsiRNA14-3-3ろ, (allI) DsiRNANeg and (alV) DsiRNA control (Mock). (b) 14-3-3 protein expression on C6/36 HT cells treated with control (Mock) (Lane 1), DsiRNANeg (Lane 2), DsiRNA14-3-3E (Lane 3) and DsiRNA14-3-3Z (Lane 4). c The expression of 14-3-3 proteins normalised against actin. Scale-bars: $100 \mu \mathrm{m}$ 
a
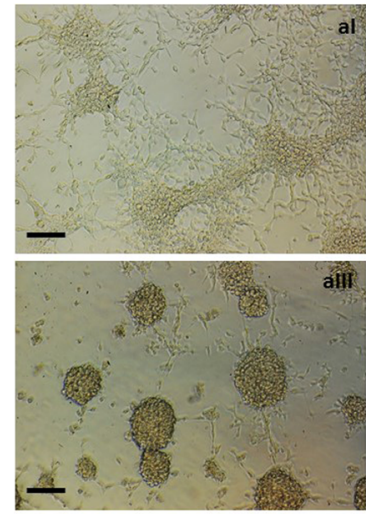

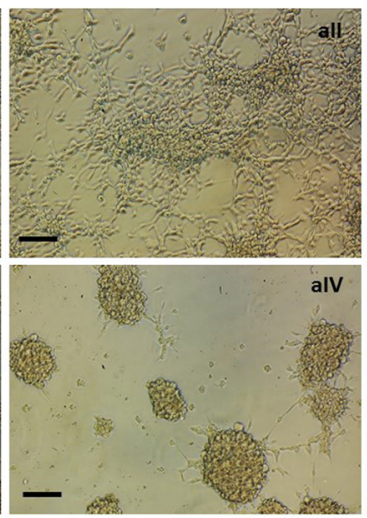

b

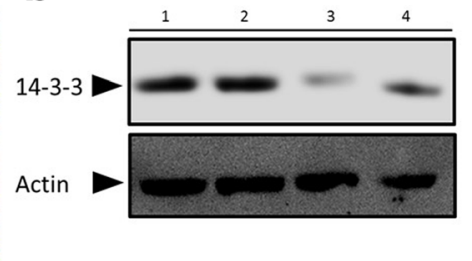

C

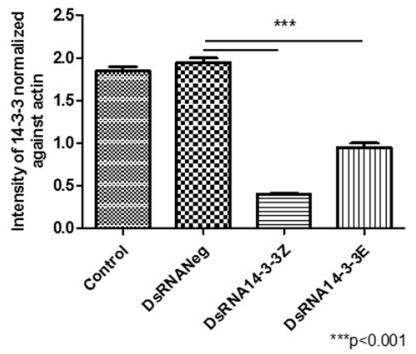

Fig. 8 DsiRNAs mediated silencing of 14-3-3 $\varepsilon$ and 14-3-3 expression on Aag-2 cells. Aag-2 cells were double transfected with DsiRNA targeting 14-3-3, and expression of 14-3-3E and 14-3-3 , proteins was assessed by Western blot. a Optical microscopy images of Aag-2 cells treated: (al) DsiRNA control (Mock), (all) DsiRNANeg, (allI) DsiRNA14-3-3 and (aIV) DsiRNA 14-3-3E. b 14-3-3 protein expression on Aag-2 cells treated with control (Mock) (Lane 1), DsiRNANeg (Lane 2), DsiRNA14-3-3E (Lane 3) and DsiRNA14-3-3Z (Lane 4). c The expression of 14-3-3 proteins normalised

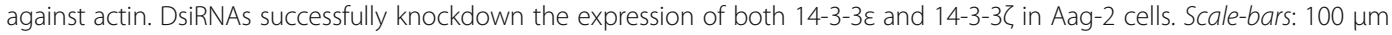

of the actin cytoskeleton and, especially, the actin depolymerising factor cofilin, which is required for the efficient phagocytosis of bacteria [3]. Besides the interaction of 14-3-3 proteins with proteins located on actin filaments, such as cofilin, interactions with other proteins has also been documented with its regulatory kinase, LIM-domain protein kinase 1 [37] and other proteins involved in attachment of the cytoskeleton to the plasma membrane and to the extracellular matrix [39, 40]. In mice astrocytes, the presence of 14-3-3 $\gamma$ was observed to be close to actin filaments as ischemia and apoptosis induced changes in the binding of 14-3-3 to F-actin [40].
Proteomic experiments in mammalian cells provide further evidence of 14-3-3 interaction with actin [15, 41]. Together, these data suggest that 14-3-3 is involved in F-actin dynamics, probably interacting with actinbinding proteins.

Phagocytosis is a rapid-acting immune mechanism of insect haemocytes representing a primary defence line that limits microbial infection [42-44]. A role of 14-3-3 proteins in phagocytosis in Drosophila was already documented $[3,9,45]$. C6/36 HT is a plasmatocyte-like cell line derived from Ae. albopictus that has been used as an experimental model for phagocytosis [46, 47]. We
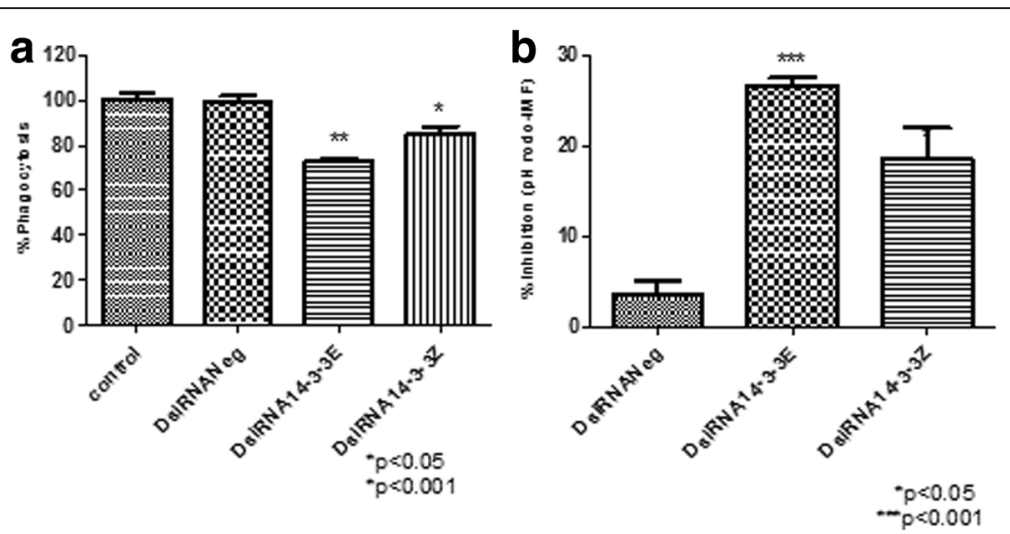

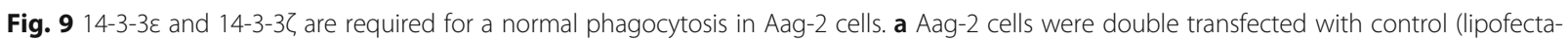
mine alone), DsiRNANeg, DsiRNA14-3-3E, and DsiRNA14-3-3Z and phagosome formation of pHrodo E. coli was evaluated. The silencing of either 14-3-3E or 14-3-3 in Aag-2 cells resulted in significant reduction of phagosome formation (a), percentage inhibition of phagocytosis (pHrodo-IMF) on the $\mathrm{C} 6 / 36 \mathrm{HT}$ silencing comparated with the control (b). Representative data from three independent experiments are shown. Experiments were performed in triplicate and represented as the mean \pm standard error, SE 
observed the reducing on S. typhimurium and E. coli uptake by $\mathrm{C6} / 36$ HT cells under treatment with the 14-3-3 inhibitor, indicating that 14-3-3 proteins participate in the internalisation (uptake) in the phagocytosis of Grampositive and Gram-negative bacteria. Considering that diminution of phagocytosis was indistinct for both Gram-positive and Gram-negative bacteria, the mechanism is probably independent of the receptor, and 14-3-3 proteins play a role in phagocytosis in a step after recognition of the target particle. Together, these results showed that 14-3-3 inhibitor is efficient in blocking the function of 14-3-3 proteins in mosquito C6/36 HT cells and causes the inhibition of phagocytosis of bacteria, indicating the participation of this protein in phagocytosis.

The exocyst complex is a molecular complex required for endo- and exo- cytosis, which is implicated in phagocytosis on Drosophila. The exocyst complex formation is an important step during phagosome biogenesis through the formation of the early phagosome [48]. We used pHrodo E. coli and S. aureus bacteria as useful markers of phagolysosome development because they become fluorescent when they are in the acidic environment of the phagolysosome $[9,28,31,49]$. In this study, C6/36 HT cells treated with the 14-3-3 inhibitor showed a significant decrease in the percentage of phagocytosis and phagolysosome formation ( $\mathrm{pHrodo}$ bright cells), indicating the involvement of 14-3-3 proteins in phagosome maturation likely in the fusion of phagosome with lysosomes at late stage of phagocytosis [50, 51], in addition to involvement of 14-3-3 proteins at early stage of phagocytosis - bacterial uptake $[48,50]$. These results are consistent with observations in haemocytes from Drosophila 14-3-3e null mutants, where bacterial internalisation, phagosome formation and maturation were also disrupted [9]. One evidence of the 14-3-3 participation in phagocytosis was the identification of 14-3-3 protein in latex bead-containing phagosomes in J774 mouse macrophage-like cell line [51]. There is also evidence for both $14-3-3 \varepsilon$ and $14-3-3 \zeta$ participation during phagocytosis of $E$. coli and $S$. aureus [3, 9]. Here, we extended the role of 14-3-3 proteins beyond phagocytosis as our results suggest that the functional impairment of 14-3-3 proteins led to defects in phagolysosome formation.

We provided an additional line of support for the role of 14-3-3 proteins in phagocytosis through silencing expression of 14-3-3 genes at the mRNA level using DsiRNAs. RNAi mechanism depends on a molecular pathway that is triggered by long exogenous double-strand RNA (dsRNA) in the cell. Dicer-2 (Dcr2) recognises and cleaves the dsRNA into small interfering RNAs (siRNAs), which usually $21 \mathrm{bp}$ initiating the RNAi pathway. The siRNA associated with Dcr2 are loaded into a multi-protein RNA-induced silencing (RISC), where it is processed (cleaved) [52-54]. We used a 27-mer instead of 21-mer of
siRNAs and took advantage of the link between Dicer and RISC systems for silencing $14-3-3 \varepsilon$ and $14-3-3 \zeta$ transcripts, as this approach can boost silencing efficiency by ca. tenfold compared with traditional siRNAs. We found very different outcomes in C6/36 HT and Aag-2 cells regarding morphology and protein expression after silencing 14-3-3 proteins. Aag-2 cells [55], showed a significant decrease in the $14-3-3 \varepsilon$ and $14-3-3 \zeta$ protein expression and marked morphological changes with 14-3-3 DsiRNA silencing, in contrast to C6/36 HT cells that did not show changes in morphology nor significant decrease in 14-3-3 protein production. It has been reported that C6/36 HT cells exhibited inefficient Dcr2 cleavage of long dsRNAs or DsiRNAs while those Aag2 cells were capable of siRNA processing. The defective expression or function of Dcr2 in C6/36 HT cells might explain the ineffective silencing likely from preventing activation of the RNAi machinery $[20,56,57]$.

It is important to note that there are some differences between C6/36 HT cells derived from Ae. albopictus larvae whole cells $[58,59]$ and Aag-2 derived from Ae. aegypti embryonic cells [60]. In addition, the C6/36 HT cells have been adapted to grow at $34{ }^{\circ} \mathrm{C}$ (they grew at $28{ }^{\circ} \mathrm{C}$ when first isolated) [61, 62]. Nevertheless, filopodia-like structures have been observed in C6/36 HT cells that were infected with Japanese encephalitis virus (grew at $28{ }^{\circ} \mathrm{C}$ ) [63]. In addition, the Aag-2 cells grew as attached fibroblast-like cells in monolayer [32] and tended to aggregate especially when cultured for a long term [32] or infected with Rift Valley fever virus [64]. The similar aggregate was likely observed in the Aag-2 cells transfected with DsiRNA in our study.

In summary, DsiRNA treatment effectively decreased $14-3-3 \varepsilon$ and $14-3-3 \zeta$ scaffold protein expression in Aag-2 cells, which resulted in cytoskeleton reorganisation and decreased phagocytosis and phagosome maturation. Our results demonstrated the involvement of 14-3-3 proteins in phagocytosis, a central mechanism of innate immune responses in mosquitoes. As DsiRNA mediated silencing $14-3-3 \varepsilon$ had a bigger impact compared to $14-3-3 \zeta$, further investigations are needed to detail differential molecular and cellular mechanisms for $14-3-3 \varepsilon$ and 14$3-3 \zeta$, including the identification of proteins partners connecting with the actin cytoskeleton and signalling pathways involved.

\section{Conclusions}

We conclude that $14-3-3 \varepsilon$ and $14-3-3 \zeta$ proteins are essential for phagocytosis of Gram-positive and Gramnegative bacteria in the Aag-2 (Ae. aegypti) and C6/36 (Ae. albopictus). The inhibition of $14-3-3 \varepsilon$ and $14-3-3 \zeta$, affected cell morphology, phagocytosis, as well as the phagosome formation, presumably by modifying cytoskeletal remodelling process. 


\section{Additional files}

Additional file 1: Fig. S1. Phagocytosis of FITC-E. coli on C6/36 HT cells. The intracellular distribution of FITC-E. coli (green) and nuclei (blue) on $\mathrm{C} 6 / 36 \mathrm{HT}$ cells at the beginning of incubation with bacteria (T0) and after $30 \mathrm{~min}$ at $34^{\circ} \mathrm{C}$ in medium alone (30 min) were visualised by immunofluorescence. (TIFF 259 kb)

Additional file 2: Fig. S2. Effect of the 14-3-3 inhibitor on the cytoskeleton organisation of $\mathrm{C} 6 / 36 \mathrm{HT}$ cells. The intracellular distribution of 14-3-3 proteins (red) and nuclei (blue) on C6/36 HT cells cultured in medium alone (MEDIUM), vehicle (DMSO) and 14-3-3 inhibitor (INHIBITOR) were visualised by immunofluorescence. (JPEG $78 \mathrm{~kb}$ )

\section{Abbreviations}

DMSO: Dimethyl sulfoxide; DsiRNAs: Dicer-substrate siRNAs; dsRNA: Doublestrand RNA; FITC: Fluorescein; GFP: Green fluorescent protein; HBSS: Hank's balanced salt solution; INH: 14-3-3 inhibitor; MEM: Minimum essential medium; RNAi: Ribonucleic acid interference; RT-PCR: Reverse transcription polymerase chain reaction; siRNAs: Small interference RNA

\section{Acknowledgements}

We especially thank Isabel Salazar by provided the Aag-2 cells, and Leticia Cortes, Juan García-Jiménez and Juan Manuel Ceballos-Ramírez, Departamento de Infectómica y Patogénesis Molecular, CINVESTAV-IPN, by laboratory support. We especially thank Jin Seon Im, Stem Cell Transplantation Research from MD Anderson Cancer Center, for English grammar support.

\section{Funding}

We thank the Consejo Nacional de Ciencia y Tecnología (CONACyT, México) by the grant (CB-83866) to FCHH, Centro de Investigación y de Estudios Avanzados del Instituto Politécnico Nacional (CINVESTAV-IPN). Abel TrujilloOcampo received a Ph.D. scholarship from CONACyT, México (290564).

\section{Availability of data and materials}

The data supporting the conclusions of this article are included within the article and its additional files.

\section{Authors' contributions}

ATO participated in the study design, carried out the Western blot assay, RT-PCR, DsiRNA design, confocal microscopy, flow cytometry, phagocytosis assays, transfection and silencing, and contributed to manuscript writing. RMA and FMR provided the C6/36 HT cells. FECR, MHR and LSA participated in the study design, interpretation data, and helped to draft the manuscript. $\mathrm{FCHH}$ participated in the study design, interpretation data, and coordination writing the manuscript. All authors read and approved the final manuscript.

\section{Ethics approval and consent to participate}

This study was approved by the CINVESTAV's Institutional Bioethical Committee for Care and Handling of Laboratory Animals (UPEAL-Protocol 013-02) following the Mexican law for humanitarian housing and management (NOM-062-ZOO-1999).

\section{Consent for publication}

Not applicable.

\section{Competing interests}

The authors declare that they have no competing interests.

\section{Author details}

'Departamento de Infectómica y Patogénesis Molecular, Centro de Investigación y de Estudios Avanzados del Instituto Politécnico Nacional (CINVESTAV-IPN), Ciudad de México, Mexico. ${ }^{2}$ Departamento de Biomedicina Molecular, Centro de Investigación y de Estudios Avanzados del Instituto Politécnico Nacional (CINVESTAV-IPN), Ciudad de México, Mexico. ${ }^{3}$ Centro de Investigación Sobre Enfermedades Infecciosas, Instituto Nacional de Salud Pública, Cuernavaca, Morelos, Mexico.
Received: 27 December 2016 Accepted: 3 July 2017

Published online: 01 August 2017

\section{References}

1. Gotthardt D, Blancheteau V, Bosserhoff A, Ruppert T, Delorenzi M, Soldati T. Proteomics fingerprinting of phagosome maturation and evidence for the role of a Galpha during uptake. Mol Cell Proteomics. 2006;5(12):2228-43.

2. Boulais J, Trost M, Landry CR, Dieckmann R, Levy ED, Soldati T, et al. Molecular characterization of the evolution of phagosomes. Mol Syst Biol. 2010;19(6):423-36

3. Ulvila J, Vanha-Aho LM, Rämet M. Drosophila phagocytosis - still many unknowns under the surface. APMIS. 2011;119(10):651-62.

4. Flannagan RS, Jaumouillé V, Grinstein S. The cell biology of phagocytosis. Annu Rev Pathol. 2012;7:61-98.

5. Kocks C, Cho JH, Nehme N, Ulvila J, Pearson AM, Meister M, et al. Eater, a transmembrane protein mediating phagocytosis of bacterial pathogens in Drosophila. Cell. 2005;123(2):335-46.

6. Etchegaray JI, Elguero EJ, Tran JA, Sinatra V, Feany MB, McCall K. Defective Phagocytic corpse processing results in neurodegeneration and can be rescued by TORC1 activation. J Neurosci. 2016:36(11):3170-83.

7. Hoffmann JA. The immune response of Drosophila. Nature. 2003;426(6962): 33-8. 8. Lemaitre B, Hoffmann J. The host defense of Drosophila melanogaster. Annu Rev Immunol. 2007;25:697-743.

8. Stuart LM, Ezekowitz RA. Phagocytosis and comparative innate immunity: learning on the fly. Nat Rev Immunol. 2008;8(2):131-41.

9. Shandala T, Woodcock JM, Ng Y, Biggs L, Skoulakis EM, Brooks DA, et al. Drosophila $14-3-3 \varepsilon$ has a crucial role in anti-microbial peptide secretion and innate immunity. J Cell Sci. 2011;124(13):2165-74.

10. Obsil T, Obsilova V. Structural basis of 14-3-3 protein functions. Semin Cell Dev Biol. 2011;22(7):663-72.

11. Skoulakis EM, Davis RL. 14-3-3 proteins in neuronal development and function. Mol Neurobiol. 1998;16(3):269-84.

12. Kong L, Lv Z, Chen J, Nie Z, Wang D, Shen H, et al. Expression analysis and tissue distribution of two 14-3-3 proteins in silkworm (Bombyx mori). Biochim Biophys Acta. 2007;1770(12):1598-604.

13. Trujillo-Ocampo A, Cázares-Raga FE, Celestino-Montes A, Cortés-Martínez L, Rodríguez MH, Hernández-Hernández FC. Identification and expression analysis of two 14-3-3 proteins in the mosquito Aedes aegypti, an important arboviruses vector. Arch Insect Biochem Physiol. 2016:93(3):143-59.

14. Roth D, Birkenfeld J, Betz H. Dominant-negative alleles of 14-3-3 proteins cause defects in actin organization and vesicle targeting in the yeast Saccharomyces cerevisiae. FEBS Lett. 1999;460(3):411-6.

15. Pozuelo Rubio M, Geraghty KM, Wong BH, Wood NT, Campbell DG, Morrice N, et al. 14-3-3-affinity purification of over 200 human phosphoproteins reveals new links to regulation of cellular metabolism, proliferation and trafficking. Biochem J. 2004:379(2):395-408

16. Freeman SA, Grinstein S. Phagocytosis: receptors, signal integration, and the cytoskeleton. Immunol Rev. 2014;262(1):193-215.

17. Thangamani S, Huang J, Hart CE, Guzman H, Tesh RB. Vertical transmission of Zika virus in Aedes aegypti mosquitoes. Am J Trop Med Hyg. 2016;95(5): 1169-73.

18. Govindarajan M, Kadaikunnan S, Alharbi NS, Benelli G. Single-step biological fabrication of colloidal silver nanoparticles using Hugonia mystax: larvicidal potential against Zika virus, dengue, and malaria vector mosquitoes. Artif Cells Nanomed Biotechnol. 2016:1-9.

19. Avila-Bonilla RG, Yocupicio-Monroy M, Marchat LA, De Nova-Ocampo MA, Del Ángel RM, Salas-Benito JS. Analysis of the miRNA profile in C6/36 cells persistently infected with dengue virus type 2. Virus Res. 2017;232:139-51.

20. Scott JC, Brackney DE, Campbell CL, Bondu-Hawkins V, Hjelle B, Ebel GD, et al. Comparison of dengue virus type 2-specific small RNAs from RNA interference-competent and -incompetent mosquito cells. PLoS Negl Trop Dis. 2010;4(10):e848.

21. Wu H, Ge J, Yao SQ. Microarray-assisted high-throughput identification of a cell-permeable small-molecule binder of 14-3-3 proteins. Angew Chem Int Ed Engl. 2010:49(37):6528-32.

22. Kaiser M, Ottmann C. The first small-molecule inhibitor of 14-3-3s: modulating the master regulator. Chembiochem. 2010;11(15):2085-7.

23. González-Calixto C, Cázares-Raga FE, Cortés-Martínez L, Del Angel RM, Medina-Ramírez F, Mosso C, et al. AealRACK1 expression and localization in response to stress in C6/36 HT mosquito cells. J Proteome. 2015;119:45-60. 
24. Kohler RS, Kettelhack H, Knipprath-Mészaros AM, Fedier A, Schoetzau A, Jacob F, et al. MELK expression in ovarian cancer correlates with poor outcome and its inhibition by OTSSP167 abrogates proliferation and viability of ovarian cancer cells. Gynecol Oncol. 2017;145(1):159-66.

25. Nibbering PH, Broug-Holub E, Bezemer AC, Jansen R, van de Winkel JG, Geertsma MF. Phagocytosis and intracellular killing of serum-opsonized Staphylococcus aureus by mouse fibroblasts expressing human Fcgamma receptor type lla (CD32). Front Biosci. 1996;1:a25-33.

26. Oliva-Ramírez J, Moreno-Altamirano MM, Pineda-Olvera B, Cauich-Sánchez P, Sánchez-García FJ. Crosstalk between circadian rhythmicity, mitochondrial dynamics and macrophage bactericidal activity. Immunology. 2014;143(3): 490-7.

27. Erwig LP, Mc Philips KA, Wynes MW, Ivetic A, Ridley AJ, Henson PM. Differential regulation of phagosome maturation in macrophages and dendritic cells mediated by rho GTPases and ezrin-radixin-moesin (ERM) proteins. Proc Natl Acad Sci USA. 2006;103(34):12825-30.

28. Miksa M, Komura H, Wu R, Shah KG, Wang P. A novel method to determine the engulfment of apoptotic cells by macrophages using pHrodo succinimidyl ester. J Immunol Methods. 2009;342(1-2):71-7.

29. Bustad HJ, Skjaerven L, Ying M, Halskau $\varnothing$, Baumann A, Rodriguez-Larrea D, et al. The peripheral binding of 14-3-3y to membranes involves isoformspecific histidine residues. PLoS One. 2012;7(11):e49671.

30. Gohla A, Bokoch GM. 14-3-3 regulates actin dynamics by stabilizing phosphorylated cofilin. Curr Biol. 2002;12(19):1704-10.

31. Colas C, Menezes S, Gutiérrez-Martínez E, Péan CB, Dionne MS, Guermonprez P. An improved flow cytometry assay to monitor phagosome acidification. J Immunol Methods. 2014;412:1-13.

32. Lan Q, Fallon AM. Small heat shock proteins distinguish between two mosquito species and confirm identity of their cell lines. Am J Trop Med Hy. 1990;43(6):669-76

33. Gao Y, Hernandez VP, Fallon AM. Immunity proteins from mosquito cell lines include three defensin a isoforms from Aedes aegypti and a defensin D from Aedes albopictus. Insect Mol Biol. 1999;8(3):311-8.

34. Aitken A. 14-3-3 proteins: a historic overview. Semin cancer biol. 2006;16(3): 162-72. 38. Tak H, Jang E, Kim SB, park J, Suk J, Yoon YS, et al. 14-3-3epsilon inhibits MK5-mediated cell migration by disrupting F-actin polymerization. Cell Signal. 2007;19(11):2379-87.

35. Ferl RJ, Manak MS, Reyes MF. The 14-3-3s. Genome Biol. 2002;3(7):REVIEWS3010.

36. Kim SA, Noh MY, Jo YH, Oh SH, Kim I, Lee YS, et al. Peptide-based polyclonal antibody against mosquito 14-3-3Z recognizes 14-3-3 homolog from dipteran and lepidopteran insects. Entomol Res. 2009;39:129-34.

37. Birkenfeld J, Betz H, Roth D. Identification of cofilin and LIM-domaincontaining protein kinase 1 as novel interaction partners of 14-3-3 zeta. Biochem J. 2003;369(Pt 1):45-54.

38. Tabunoki H, Shimada T, Banno Y, Sato R, Kajiwara H, Mita K, et al. Identification of Bombyx mori 14-3-3 orthologs and the interactor Hsp60. Neurosci Res. 2008;61(3):271-80.

39. Mackintosh C. Dynamic interactions between 14-3-3 proteins and phosphoproteins regulate diverse cellular processes. Biochem J. 2004;381 (Pt 2):329-42.

40. Chen $X Q, Y u A C$. The association of 14-3-3gamma and actin plays a role in cell division and apoptosis in astrocytes. Biochem Biophys Res Commun. 2002;296(3):657-63.

41. Liang S, Yu Y, Yang P, Gu S, Xue Y, Chen X. Analysis of the protein complex associated with 14-3-3 epsilon by a deuterated-leucine labeling quantitative proteomics strategy. J Chromatogr B Analyt Technol Biomed Life Sci. 2009;877(7):627-34.

42. Hillyer JF, Schmidt SL, Fuchs JF, Boyle JP, Christensen BM. Age-associated mortality in immune challenged mosquitoes (Aedes aegypti) correlates with a decrease in haemocyte numbers. Cell Microbiol. 2005;7(1):39-51.

43. Haine ER, Moret $Y$, Siva-Jothy MT, Rolff J. Antimicrobial defense and persistent infection in insects. Science. 2008;322(5905):1257-9.

44. Oliver JD, Dusty Loy J, Parikh G, Bartholomay L. Comparative analysis of hemocyte phagocytosis between six species of arthropods as measured by flow cytometry. J Invertebr Pathol. 2011;108(2):126-30.

45. Agaisse H, Burrack LS, Philips JA, Rubin EJ, Perrimon N, Higgins DE. Genome-wide RNAi screen for host factors required for intracellular bacterial infection. Science. 2005;309(5738):1248-51.

46. Mizutani T, Kobayashi M, Eshita Y, Inanami O, Yamamori T, Goto A, et al. Characterization of JNK-like protein derived from a mosquito cell line, C6/36. Insect Mol Biol. 2003;12(1):61-6.
47. Mizutani T, Kobayashi M, Eshita Y, Shirato K, Kimura T, Ako Y, et al. Involvement of the JNK-like protein of the Aedes albopictus mosquito cell line, C6/36, in phagocytosis, endocytosis and infection of West Nile virus. Insect Mol Biol. 2003:12(5):491-9.

48. Stuart LM, Boulais J, Charriere GM, Hennessy EJ, Brunet S, Jutras I, et al. A systems biology analysis of the Drosophila phagosome. Nature. 2007; 445(7123):95-101.

49. Neaga A, Lefor J, Lich KE, Liparoto SF, Xiao YQ. Development and validation of a flow cytometric method to evaluate phagocytosis of pHrodo $^{\text {TM }}$ BioParticles ${ }^{\circledast}$ by granulocytes in multiple species. J Immunol Methods. 2013;390(1-2):9-17.

50. Ulvila J, Vanha-aho LM, Kleino A, Vähä-Mäkilä M, Vuoksio M, Eskelinen S, et al. Cofilin regulator 14-3-3zeta is an evolutionarily conserved protein required for phagocytosis and microbial resistance. J Leukoc Biol. 2011;89(5):649-59.

51. Garin J, Diez R, Kieffer S, Dermine JF, Duclos S, Gagnon E, et al. The phagosome proteome: insight into phagosome functions. J Cell Biol. 2001;152(1):165-80.

52. Bernstein E, Caudy AA, Hammond SM, Hannon GJ. Role for a bidentate ribonuclease in the initiation step of RNA interference. Nature. 2001; 409(6818):363-6.

53. Elbashir SM, Lendeckel W, Tuschl T. RNA interference is mediated by 21- and 22-nucleotide RNAs. Genes Dev. 2001;15(2):188-200.

54. Nykanen A, Haley B, Zamore PD. ATP requirements and small interfering RNA structure in the RNA interference pathway. Cell. 2001;107(3):309-21.

55. Barletta $A B$, Silva MC, Sorgine MH. Validation of Aedes aegypti Aag-2 cells as a model for insect immune studies. Parasit Vectors. 2012;5:148-56.

56. Morazzani EM, Wiley MR, Murreddu MG, Adelman ZN, Myles KM. Production of virus-derived ping-pong-dependent piRNA-like small RNAs in the mosquito soma. PLoS Pathog. 2012;8(1):e1002470.

57. Brackney DE, Scott JC, Sagawa F, Woodward JE, Miller NA, Schilkey FD, et al. C6/36 Aedes albopictus cells have a dysfunctional antiviral RNA interference response. PLoS Negl Trop Dis. 2010;4(10):e856.

58. Igarashi A. Isolation of a Singh's Aedes albopictus cell clone sensitive to dengue and chikungunya viruses. J Gen Virol. 1978;40(3):531-44.

59. Singh KR, Pavri KM. Experimental studies with chikungunya virus in Aedes aegypti and Aedes albopictus. Acta Virol. 1967;11(6):517-26.

60. Peleg J, Shahar A. Morphology and behaviour of cultured Aedes aegypti mosquito cells. Tissue Cell. 1972;4(1):55-62.

61. Alcalá AC, Medina F, González-Robles A, Salazar-Villatoro L, Fragoso-Soriano RJ, Vásquez C, et al. The dengue virus non-structural protein 1 (NS1) is secreted efficiently from infected mosquito cells. Virology. 2016;488:278-87.

62. Mosso C, Galván-Mendoza IJ, Ludert JE, del Angel RM. Endocytic pathway followed by dengue virus to infect the mosquito cell line C6/36 HT. Virology. 2008;378(1):193-9.

63. Tsai KN, Tsang SF, Huang CH, Chang RY. Defective interfering RNAs of Japanese encephalitis virus found in mosquito cells and correlation with persistent infection. Virus Res. 2007;124(1-2):139-50.

64. Léger $\mathrm{P}$, Lara $\mathrm{E}$, Jagla B, Sismeiro O, Mansuroglu Z, Coppée JY, et al. Dicer-2- and Piwi-mediated RNA interference in Rift Valley fever virusinfected mosquito cells. J Virol. 2013:87(3):1631-48.

\section{Submit your next manuscript to BioMed Central and we will help you at every step:}

- We accept pre-submission inquiries

- Our selector tool helps you to find the most relevant journal

- We provide round the clock customer support

- Convenient online submission

- Thorough peer review

- Inclusion in PubMed and all major indexing services

- Maximum visibility for your research

Submit your manuscript at www.biomedcentral.com/submit 